\title{
Implementation of Green Procurement in Supplier Selection of PT Kubota Indonesia with Fuzzy Analytical Network Process Approach (FANP)
}

\author{
Darminto Pujotomo $^{1 *}$, Erpita Rahcman ${ }^{1}$, Trio Budi Prasetiyo Utomo ${ }^{1}$ \\ ${ }^{1}$ Industrial Engineering Department, Faculty of Engineering, Diponegoro University, Semarang - Indonesia
}

\begin{abstract}
Industry globalization and consumer concern for environmental issues compel the industry to make adjustments to the green industry concept including green procurement activities such as supplier selection. One of the industries in the diesel engine exporting company, PT. Kubota Indonesia, must be able to meet market demands related to Green Industries. one of the Green Industry Concepts that teaches companies to broaden their perspectives on corporate environmental concerns is Green Procurement. This concept emphasizes companies to use suppliers who also have a concern for the environment. When conducting the supplier selection process PT. Kubota Indonesia only emphasizes on the criteria for quality, price and timely delivery. In addition, delays in orders received at the company make this company have to choose suppliers. The results of this study were to determine the criteria and sub-criteria weights used by PT. Kubota Indonesia selects suppliers according to the concept of Green Procurement, ranks and selects suppliers using Fuzzy Analytical Network Process (FANP). The most important criteria are quality criteria and the best supplier recommended is PT. Three Pamindo T
\end{abstract}

Keywords: supplier selection; Green Procurement; Fuzzy Analytical Network Process (FANP)

\section{Introduction}

Today consumers are always selective in purchasing products to support environmental viability and this is known as the Green Consumer. In the concept of green consumers, there is research that states that 6 out of 10 consumers in America, prefer to purchase green products rather than environmental products, and this will force existing industries to adapt to this concept in every business process (green industries)[1].

One part of the green industries concept that concerns supply chain management and procurement is the concept of green procurement [2]. Green procurement is defined as a management process that governs the relationships between suppliers, materials or raw materials, as well as the natural or human environment [3]. The concept of green procurement is the principle of environmental protection into supplier management systems. One of the most important parts in the procurement process business is the selection of suppliers. Conventional supplier selection generally uses quality criteria, delivery time, price and service but still not paying attention to environmental factors.

In a study conducted [4] states that the concept of greening in suppliers through green innovation contributes significant benefits to environmental performance and corporate competitive advantage. The concept of green procurement for PT Kubota is not a new thing for the company, which has indeed been committed to environmental sustainability.

The results of this study were to determine the criteria and sub-criteria weights used by PT. Kubota Indonesia selects suppliers according to the concept of Green Procurement, ranks and selects suppliers using Fuzzy Analytical Network Process (FANP).

\section{Methodology}

\subsection{Identification of the Green Procurement- based Supplier Selection Criteria}

In the identification of these criteria is done literature studies on criteria and sub criteria that reflect producers or suppliers who care for the environment. As a result of the literature study, the criteria were obtained to select Green Supplier based on the research [5]. In addition to supplier selection criteria, this phase also incorporates supplier selection criteria conducted [6]. The sub criteria used refers to the research and adjusted to the condition of PT. Kubota Indonesia. The Supplier Selection criteria and sub criteria shown in Table 1.

* Corresponding author: darminto_pujotomo@yahoo.com 
Table 1. Supplier Selection Criteria and Sub Criteria.

\begin{tabular}{|c|c|c|}
\hline No & Criteria & Sub Criteria \\
\hline \multirow{5}{*}{1} & \multirow{5}{*}{ Quality } & Control of Products Defect \\
\hline & & Return Rate \\
\hline & & Certificate for Quality \\
\hline & & Quality management capability \\
\hline & & Capability to handle abnormal quality \\
\hline \multirow{2}{*}{2} & \multirow{2}{*}{ Price } & Bid price \\
\hline & & Discounts \\
\hline \multirow{2}{*}{3} & \multirow{2}{*}{ Delivery } & Lead Time \\
\hline & & Ontime Delivery rate \\
\hline \multirow{3}{*}{4} & \multirow{3}{*}{ Service } & Warranty \\
\hline & & Procedure legality \\
\hline & & Communication \\
\hline \multirow{3}{*}{5} & \multirow{3}{*}{ Organization } & Historical Performance \\
\hline & & Resource \\
\hline & & Production Capacity \\
\hline \multirow{2}{*}{6} & \multirow{2}{*}{$\begin{array}{l}\text { Technology } \\
\text { Capability }\end{array}$} & Technology level \\
\hline & & Research and Development Capability \\
\hline \multirow[b]{2}{*}{7} & \multirow{2}{*}{$\begin{array}{l}\text { Environmental } \\
\text { Management }\end{array}$} & Environmental related certificates \\
\hline & & $\begin{array}{l}\text { Regular monitoring and regulatory } \\
\text { compliance }\end{array}$ \\
\hline \multirow{2}{*}{8} & \multirow{2}{*}{ Green Product } & green packaging \\
\hline & & Green raw material \\
\hline
\end{tabular}

\subsection{Questionnaire Design}

The questionnaire used in this study is a closed questionnaire. Questionnaires are used to obtain data on the importance level of criteria and perceptions of management related parties to suppliers. The questionnaire used is a questionnaire based on Saaty's Scale where answers are made by looking at the importance values between the criteria. The assessment system on the questionnaire can be seen in table 2 .

Table 2. Questionnaire Criteria Rating System Based on Fuzzy Numbers Saaty's Scale.

\begin{tabular}{clc}
\hline $\begin{array}{c}\text { Numerical } \\
\text { Rating for } \boldsymbol{A N P}\end{array}$ & \multicolumn{1}{c}{$\begin{array}{c}\text { Linguistic Scale for } \\
\text { Importance }\end{array}$} & $\begin{array}{c}\text { Triangular Fuzzy } \\
\text { Scale }(\mathbf{l}, \mathbf{m}, \mathbf{u})\end{array}$ \\
\hline 1 & Equally importance & $(1,1,3)$ \\
\hline 3 & Weak importance & $(1,3,5)$ \\
\hline 5 & Strong importance & $(3,5,7)$ \\
\hline 7 & Very strong importance & $(5,7,9)$ \\
\hline 9 & Extremely importance & $(7,9,9)$ \\
\hline
\end{tabular}

\subsection{Distribution of Questionnaires}

The distribution of this questionnaire was conducted to the decision maker in PT. Kubota Indonesia. The submission of questionnaires to obtain the weight of each criterion and sub criteria, and to obtain the performance value of each supplier. Decison maker in this company is done by the manager of Purchasing Department and his assistant with special duty to make supplier selection, as well as production department and department quality control.

\subsection{Determination of Weight Criteria Using Fuzzy ANP Method}

In determining the criteria weight for supplier selection assessment using Fuzzy ANP method. ANP was chosen because of its superiority in capturing the interaction of interdepensions and interdepensions between criteria and sub criteria. The use of fuzzy in this study is to accommodate the vague nature of decision making to provide judgment which can overcome the uncertainty in qualitative criteria. The fuzzy stages of ANP are as follows :

\subsubsection{Collecting Linguistic Variable Values}

At this stage the questionnaire data was collected to obtain the importance of each criterion. Questionnaires used to perform pairwise comparison between alternatives using linguistic variables.

In table 3. is an sample of a linguistic summary of the first part of the questionnaire

Table 3. Sample Recapitulation of Linguistic Variable Questionnaire Part One First Comparison.

\begin{tabular}{|c|c|c|c|c|c|}
\hline \multirow[b]{2}{*}{ Citeria 1} & \multicolumn{4}{|c|}{ Respondent } & \multirow[b]{2}{*}{ Citeria 2} \\
\hline & $\begin{array}{l}\text { Manager } \\
\text { Purchase }\end{array}$ & $\begin{array}{c}\text { Asisten } \\
\text { Purchase }\end{array}$ & Production & QC & \\
\hline $\begin{array}{l}\text { Quality } \\
\text { management } \\
\text { capability }\end{array}$ & $\sim \mathrm{W}$ & $\sim \mathrm{W}$ & $\sim \mathrm{W}$ & $\sim \mathrm{S}$ & $\begin{array}{l}\text { Capability } \\
\text { to handle } \\
\text { abnormal } \\
\text { quality }\end{array}$ \\
\hline
\end{tabular}

\subsubsection{Fuzzyfication}

Questionnaires used to perform pairwise comparison between alternatives using linguistic variables, to perform subsequent data processing then the linguistic variables need to be converted into fuzzy numbers. At this stage the questionnaire data is transformed into Fuzzy Triangular Number [7].

In table 4. is an Recapitulation Triangular Fuzzy Scale Questionnaire Part One First Comparison.

Table 4. Sample of Recapitulation Triangular Fuzzy Scale Questionnaire Part One First Comparison.

\begin{tabular}{|l|c|c|c|c|c|c|c|c|c|c|c|c|c|}
\hline \multirow{2}{*}{$\begin{array}{l}\text { Alternative } \\
1\end{array}$} & \multicolumn{7}{|c|}{ Responden } & \multirow{2}{*}{$\begin{array}{c}\text { Alternativel } \\
2\end{array}$} \\
\cline { 2 - 12 } & \multicolumn{2}{|c|}{$\begin{array}{c}\text { Manager } \\
\text { Purchase }\end{array}$} & \multicolumn{2}{|c|}{$\begin{array}{c}\text { Asisten } \\
\text { Purchase }\end{array}$} & \multicolumn{2}{|c|}{ Production } & \multicolumn{3}{|c|}{ QC } & \\
\hline & C & A & B & C & A & B & C & A & B & C & A & B & \\
\hline $\begin{array}{l}\text { Quality } \\
\text { management } \\
\text { capability }\end{array}$ & 5 & 3 & 1 & 5 & 3 & 1 & 5 & 3 & 1 & 7 & 5 & 3 & $\begin{array}{l}\text { Capability } \\
\text { to handle } \\
\text { abnormal } \\
\text { quality }\end{array}$ \\
\hline
\end{tabular}




\subsubsection{Calculating Average Geometric Questionnaire Overall}

After translating the linguistic variables into fuzzy triangular numbers where each value is translated into the fuzzy set, the next step is to combine each of the lower bound (C), the mean (A), and the upper (B) of the three questionnaires into each one value, lower value (C), middle value (A), and upper value (B) for each pairwise ratio [8].

$$
\begin{aligned}
& C=\sqrt[n]{c 1 \times c 2 \times c 3 x \ldots x c n} \ldots \\
& A=\sqrt[n]{a 1 x a 2 x a 3 x \ldots x a n} . \\
& B=\sqrt[n]{b 1 x b 2 x b 3 x \ldots x b n} . \\
& \mathrm{n}=\text { number of respondents }
\end{aligned}
$$

Here is a sample calculation for the first first comparison questionnaire :

$$
\begin{aligned}
& c=\sqrt[4]{c 1 \cdot c 2 \cdot c 3 \cdot c 4}=\sqrt[4]{5 \cdot 5 \cdot 5 \cdot 7}=5.4388 \\
& a=\sqrt[4]{a 1 \cdot a 2 \cdot a 3 \cdot a 4}=\sqrt[4]{3.3 .3 .5}=3.4085 \\
& b=\sqrt[4]{b 1 \cdot b 2 \cdot b 3 \cdot b 4}=\sqrt[4]{1 \cdot 1 \cdot 1 \cdot 3}=1.3161
\end{aligned}
$$

\subsubsection{Defuzzyfication}

In this study, defuzzification uses the center of gravity (COG) method, where three values of the geometric average geometric Fuzzy Triangular $(\mathrm{C}, \mathrm{A}, \mathrm{B})$ numbers will be converted to a crips value for later input into data processing using ANP [9]. In this research will be used method of center of gravity. This method is the most common method and most widely proposed by many researchers used. This mathematical formulation can be given as follows :

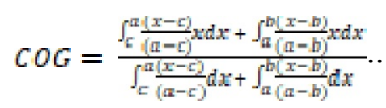

Here is an example of a first questionnaire defuzzification calculation section of the first comparison (quality management capability compared with capability to handle abnormal quality),

$$
\begin{aligned}
& \int_{5-43879}^{3.4086} \frac{(x-5.43-479)}{(3.40-16-6-54879)} x d x \\
& C O G=\frac{+\int_{3.40866(3.40166-131607)}^{1.31607} d x}{\int_{5.43879}^{3.4046(3.40-5.43879)} d x} \\
& +\int_{3.40 \sin }^{1.3160} \frac{(x-1.31607)}{(3.40866-131607)} d x \\
& =3.388
\end{aligned}
$$

\subsubsection{Preparation of Pairwise Matrices}

The preparation of pairwise comparison matrices to be transformed in the form of pairwise comparison matrices for numerical analysis.

\subsubsection{Consistency Test}

At this stage, a paired comparison matrix will be tested for consistency by looking at the CR value should be less than 0.1. A pairwise comparison matrix will be consistent when the inconsistency index is below 0.1 . This is important because in the absence of inconsistency changes that affect the level of preference do not apply. If the pairwise pair mastriks are inconsistent then it is necessary to rearrange the comparison matrix.

Based on the calculations, all the results of the comparison questionnaire have a consistency value below 0.1 . Fig. 1, is one example of the output of super decision software for consistency value calculation and recap value results for all comparison questionnaires.

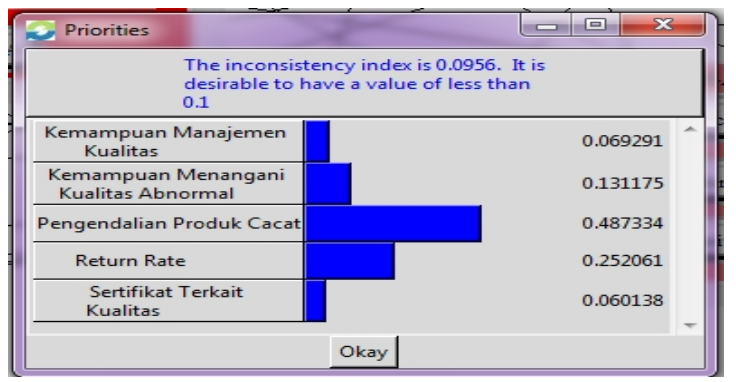

Fig. 1. Consistency Test Comparison between Criteria in Subcriteria of Control of Products Defect.

\subsubsection{Calculation of Local Priority Weight}

Having obtained a value of crips for the assessment of each relationship of the fuzzy method, the next step is to calculate the local priority weight. This calculation aims to determine the weight of each interconnected element. Each weighted local priority, the value of consistency must be considered.

In determining the weight of each criterion for supplier selection using super decision software. To recapitulate the weight of each supplier selection criteria can be seen in table 5 .

\subsubsection{Determination of Weight and Ranking Supplier}

Supplier selection is one of the problems that can be done with Fuzzy ANP (Analytical Network Process). After making supermatriks it will get the weight for each supplier and with the weight can be established supplier rankings. After calculating the weight of each criterion and supplier alternative using super decision software, the company can determine which alternatives will be chosen based on the weighting of each alternative. The following is a ranking for each selected supplier criteria and alternatives, can be seen in table 6 . 
Table 5. Recapitulation of Results Calculation of Local Priority Weights Each Criteria and Each Sub Criteria.

\begin{tabular}{|c|c|c|c|c|}
\hline No & Criteria & Weight & Sub Criteria & Weight \\
\hline \multirow{5}{*}{1} & \multirow{5}{*}{ Quality } & \multirow{5}{*}{0.230} & Control of Products Defect & 0.47233 \\
\hline & & & Return Rate & 0.33026 \\
\hline & & & Certificate for Quality & 0.04013 \\
\hline & & & Quality management capability & 0.0632 \\
\hline & & & Capability to handle abnormal quality & 0.09409 \\
\hline \multirow{2}{*}{2} & \multirow{2}{*}{ Price } & \multirow{2}{*}{0.185} & Bid price & 0.67026 \\
\hline & & & Discounts & 0.32974 \\
\hline \multirow{2}{*}{3} & \multirow{2}{*}{ Delivery } & \multirow{2}{*}{0.129} & Lead Time & 0.32898 \\
\hline & & & Ontime Delivery rate & 0.67102 \\
\hline \multirow{3}{*}{4} & \multirow{3}{*}{ Service } & \multirow{3}{*}{0.055} & Warranty & 0.73289 \\
\hline & & & Procedure legality & 0.12105 \\
\hline & & & Communication & 0.14606 \\
\hline \multirow{3}{*}{5} & \multirow{3}{*}{ Organization } & \multirow{3}{*}{0.055} & Historical Performance & 0.30812 \\
\hline & & & Resource & 0.12701 \\
\hline & & & Production Capacity & 0.56487 \\
\hline \multirow{2}{*}{6} & \multirow{2}{*}{$\begin{array}{l}\text { Technology } \\
\text { Capability }\end{array}$} & \multirow{2}{*}{0.146} & Technology level & 0.96951 \\
\hline & & & Research and Development Capability & 0.03049 \\
\hline \multirow[b]{2}{*}{7} & \multirow{2}{*}{$\begin{array}{l}\text { Environmental } \\
\text { Management }\end{array}$} & \multirow[b]{2}{*}{0.099} & Environmental related certificates & 0.67367 \\
\hline & & & $\begin{array}{l}\text { Regular monitoring and regulatory } \\
\text { compliance }\end{array}$ & 0.32633 \\
\hline \multirow{2}{*}{8} & \multirow{2}{*}{ Green Product } & \multirow{2}{*}{0.100} & green packaging & 0.66413 \\
\hline & & & Green raw material & 0.33587 \\
\hline
\end{tabular}

Table 6. Ranking of Supplier Criteria

\begin{tabular}{|l|c|c|}
\hline \multicolumn{1}{|c|}{ Supplier Criteria } & Weight & Ranking \\
\hline Quality & 0.230 & 1 \\
\hline Price & 0.185 & 2 \\
\hline Delivery & 0.129 & 4 \\
\hline Service & 0.055 & 7 \\
\hline Organization & 0.055 & 8 \\
\hline Technology Capability & 0.146 & 3 \\
\hline Environmental Management & 0.099 & 6 \\
\hline Green Product & 0,100 & 5 \\
\hline
\end{tabular}

As for the priority of the supplier as shown in table 7 .

Table 7. Weight of Supplier Performance based on Green Procurement Criteria

\begin{tabular}{|l|c|c|}
\hline \multicolumn{1}{|c|}{ Supplier Alternative } & Weight & Ranking \\
\hline Artima Industry Indonesia & 0.145 & 4 \\
\hline Asama Indonesia & 0.134 & 5 \\
\hline AT Indonesia & 0.204 & 2 \\
\hline Pakarti Riken Indonesia & 0.193 & 3 \\
\hline Pamindo Tiga T & 0.324 & 1 \\
\hline
\end{tabular}

Based on data collection and processing conducted in supplier selection research based on Green Procurement, PT. Pamindo Tiga $\mathrm{T}$ becomes the recommended supplier for the company

\section{Result And Discussion}

Based on the table. 6, In the selection of green procurement-based suppliers, quality criteria become the criteria with the highest weight in the criteria companies choose suppliers. Permanent quality criteria can not be ignored in the selection of a supplier although the supplier selection criteria used this time is Green Procurement criteria. This is because with the quality materials supplied by the supplier will also produce a quality product. In addition, quality will also determine the level of customer satisfaction and production costs of the company.

Price criteria occupies the second position on the assessment of the company in choosing a supplier. Although the supplier selection criteria used this time apply Green Procurement criteria, cost can not be ignored in the selection of a supplier. This is because the cost criteria can affect the cost used to produce a product. Companies will definitely consider suppliers who are able to provide the lowest bid price

The criteria of technology capability occupy the third position in the appraisal of a company choosing a supplier. In the concept of green procurement, the company is expected to be able to hold material from suppliers who care about the environment. companies can see this through how the technology used by suppliers so as to meet the criteria related to the environment.

In table 7 , based on data collection and processing conducted on the research of supplier selection based on Green Procurement, PT. Pamindo Tiga T becomes the recommended supplier to the company. Meanwhile, the company currently uses Asama Indonesia supplier selected based on traditional supplier selection method (price, quality, and on time delivery) for the product. Thus it can be seen that the suppliers used by the company now have a lower environmental performance value than the suppliers recommended in this study.

\section{Conclusions and Recommendations}

In the process of selecting suppliers based on Green Procurement at PT Kubota Indonesia there are 8 criteria and $21 \mathrm{sub}$ criteria influential. The weighting result with the highest quality criterion has the biggest weight, the price criteria has the second biggest weight, and the technology capability has the third biggest weight, as the green product and the environmental management are fifth and sixth.

This innovation strategy focuses on quality and technical and production capabilities [10]. Quality criteria ranked first and technology capability ranked third, indicating that PT Kubota does lead to innovation strategies that focus on quality and technical and production capability. 


\section{References}

1. Ferraro, Carla. The Green Consumer. (The ACRS Thought Leadership Series, 2009).

2. Brugman, D Claudio. http://eprints.undip.ac.id/38668/1/L2H008019.pdf (2013).

3. Yeh, Wei-Chang, Chuang, Mei-Chi. Expert Systems with Applications, 38, 4244-4253 (2011)

4. Chiou, Tzu-Yun \& Chan, Hing Kai \& Lettice, Fiona \& Chung, Sai Ho, Transportation Research Part E: Logistics and Transportation Review, 47 (6), 822836 (2011)

5. Lee, A. H. I., Kang, H.-Y., Hsu, C.-F., \& Hung, H.C. Expert Systems with Applications, 36, 79177927 (2009)
6. Chen, Yuh-Jen. Journal of Information Sciences, 181, 1651-1670 (2010)

7. Saaty, Thomas L., Decision Making with Dependence and Feedback: The Analytic Network Process. (Pittsburgh : RWS Publication, 1996)

8. Putri, MS Soerya. http://eprints.binus.ac.id/6516/ (2011)

9. Paramitha, Silvia, Usman Effendi, Ika Atsari Dewi, Jurnal; Industri, 1 No. 3, 159 -171 (2012).

10. Yang, Chen-Lung, \& Lin, Shu-Ping \& Chan \& Chwen Sheu, International Journal of Production Economics, 123, Issue 1, 210-220 (2010). 